\title{
Rearticulating the Case for Minority Language Rights
}

\author{
Stephen May \\ School of Education, University of Waikato, Private Bag, 3105, Hamilton, New \\ Zealand
}

While advocacy of minority language rights (MLR) has become well established in sociolinguistics, language policy and planning and the wider human rights literature, it has also come under increased criticism in recent times for a number of key limitations. In this paper, I address directly three current key criticisms of the MLR movement. The first is a perceived tendency towards essentialism in articulations of language rights. The second is the apparent utopianism and artificiality of 'reversing language shift' in the face of wider social and political 'realities'. And the third is that the individual mobility of minority-language speakers is far better served by shifting to a majority language. While acknowledging the perspicacity of some of these arguments, I aim to rearticulate a defence of minority language rights that effectively addresses these key concerns. This requires, however, a sociohistorical/sociopolitical rather than a biological/ecological analysis of MLR. In addition, I will argue that a sociohistorical/sociopolitical defence of MLR can problematise the positions often adopted by minority language rights' critics themselves, particularly those who defend majoritarian forms of linguistic essentialism and those who sever the instrumental/identity aspects of language. Implications for language policy and planning will also be discussed.

Keywords: language rights, linguistic ecology, minority languages

\section{Introduction}

In recent years, advocacy of minority language rights (MLR) has become increasingly well established in the sociology of language, sociolinguistics, language policy and planning, and the wider human rights literature. This advocacy is most clearly demonstrated in and by three distinct, albeit closely interrelated, academic movements. One is the Language Ecology (LE) movement, charting the links between linguistics and ecology, and situating the current exponential loss of many of the world's languages within a wider ecological framework (see e.g. Harmon, 1995; Maffi, 2000, 2001; Mühlhäusler, 1996, 2000; Nettle \& Romaine, 2000). A second is the linguistic human rights (LHR) movement that argues, often on the basis of LE premises, for the greater institutional protection and support of minority languages, ${ }^{1}$ and their speakers, both within national and supranational contexts (see e.g. Kontra et al., 1999; Phillipson, 2003; Skutnabb-Kangas, 1998, 2000, 2002; Skutnabb-Kangas \& Phillipson, 1995). These arguments are also echoed in a third domain of academic legal discourse that has developed with respect to minority group rights generally, but with an increasing focus on the specific implementation of minority language rights in national and international law (see e.g. Capotorti, 1979; de Varennes, 1996a,b; Henrard, 2000; Thornberry, 1991a,b).

Taken together, these three movements have generated considerable momentum for the academic and political articulation of MLR in recent times. They have 
also exerted a growing influence on debates on language policy and planning (LPP), in particular by highlighting the often highly discriminatory processes that stigmatise and undermine minority languages and their speakers - not only linguistically, but also culturally, socially, economically and politically. Accordingly, even when language rights are not the principal focus of attention, research and policy in LPP is increasingly having to address these concerns (see e.g. Kaplan \& Baldauf, 1999; May, 2005; Ricento, 2000; Tollefson, 2001). However, there is also increasing criticism, from both within and without, about certain key tenets of MLR.

In this paper, I wish to address directly, and respond to, three of these key criticisms. The first is a perceived tendency towards essentialism in articulations of MLR - that languages and identities are always ineluctably linked. A second criticism relates to the inherent 'preservationism' and 'romanticism' of minority languages and their loss, particularly within LE, thus highlighting both the utopianism and artificiality of 'reversing language shift' in the face of wider social and political 'realities'. The third is an allied argument that the individual mobility of minority-language speakers is far better served by shifting to a majority language - that the MLR movement is responsible, in effect, for ghettoising minority-language speakers. ${ }^{2}$

While acknowledging the perspicacity of some of these arguments, I aim in this paper to rearticulate a defence of minority language rights that effectively addresses these key concerns. To do so, however, requires a fundamental shift in current theorising about MLR away from the biological/ecological analysis of LE, and some linguistic human rights (LHR) arguments, to a more overtly sociohistorical/ sociopolitical analysis. This shift is crucial because it allows one to avoid an essentialist construction of language and identity, while at the same time still being able to highlight and examine the often central role and influence of language and identity in many ethnic/national conflicts in the world today. From this, one can also provide a critique of the positions adopted by many language rights' critics themselves, particularly those who defend majoritarian forms of linguistic essentialism and those who sever the instrumental/identity aspects of language.

In order to address these three particular criticisms of MLR, I will first outline each of them in detail, before responding to each of them in turn.

\section{The 'Essentialist Tendency'}

A consistent criticism levelled against arguments for MLR is their tendency towards essentialism. Essentialism is taken to mean here the process by which particular groups come to be described in terms of fundamental, immutable characteristics - as, for example, via a particular language-identity link. In so doing, the relational and fluid aspects of identity formation are ignored and the group itself comes to be seen as autonomous, separate, and static, as impervious to context, time, and historical processes of change, as well as to ongoing processes of internal and external differentiation (Werbner, 1997).

This 'essentialist tendency', closely allied with an often deterministic account of the links between language, identity, and the wider ecological system, is most evident in arguments for language ecology (LE), as well as in those linguistic 
human rights (LHR) arguments that are predicated on LE principles. This is because the biological/ecological assumptions underpinning these analyses, by definition, presuppose the intrinsic interconnectedness of language, identity, and the wider ecological system. Such arguments assume - in their less sophisticated manifestations, explicitly, and even in their most sophisticated forms, at least implicitly - an almost ineluctable connection between language and (ethnic) identity. This often unquestioned language/identity link is then used, in turn, to justify any associated 'collective' MLR claims.

The charge of essentialism is levelled most often, and most vociferously, by avowed sceptics of MLR, both within sociolinguistics and wider social and political theory. It is also a criticism levelled by a number of sociolinguists, linguistic anthropologists, and critical linguists, including myself, who remain broadly sympathetic to MLR. It is not always easy to differentiate these groups, or at least to situate those who might lie at the margins or border of each. However, broadly speaking, the former regard essentialism as an endemic and inherently debilitating characteristic of MLR, ${ }^{3}$ while the latter acknowledge the central problem of essentialism, but actively explore ways by which this might be addressed (for examples here, see Blommaert, 2001; Heller, 1999; May, 2000a, 2001, 2003; Norton, 2000; Pennycook, 2001).

A particular challenge for advocates of MLR in this regard is the widespread consensus in social and political theory, and increasingly in sociolinguistics and critical applied linguistics, that language is at most only a contingent factor of one's identity. In other words, language does not define who people are, and may not be an important feature, or indeed even a necessary one, in the construction of their identities, whether at the individual or collective levels. This view has been put forward in sociolinguistics by, among others, Carol Eastman (1984) and John Edwards $(1985,1994)$, who have argued that language is often only a secondary or surface characteristic of ethnicity (see also Bentahila \& Davies, 1993; Coulmas, 1992). The consequence of such a view is obvious - if language-use is merely a surface feature of ethnic identity, adopting another language would only affect the language use aspect of ethnic identity, not the identity itself. Thus, the loss of a particular language is not the 'end of the world' for a particular ethnic identity - the latter simply adapts to the new language. As Eastman asserts, 'there is no need to worry about preserving ethnic identity, so long as the only change being made is in what language we use' (Eastman, 1984: 275).

Edwards (1985) develops a broadly comparable argument on the detachability of language from identity when he asserts that economic rationality often plays a part in the language choices individuals make, particularly when individuals realise the 'benefits' of shifting to a more 'modern' language. ${ }^{4}$ On this view, loyalty to a particular language persists only as long as the economic and social circumstances are conducive to it (see also Coulmas, 1992; Dorian, 1981, 1982). As Edwards (1985) proceeds to observe, this contrasts with what he sees as the clearly regressive interests of MLR proponents:

Note here how patronising and naive are attempts to preserve people as they are, on the grounds that they are really better off if only they knew it, that progress is not all it is made out to be ... Little wonder, then, that sensible 
populations themselves do not accept this line, and that the major proponents of the view [minority elites] are usually securely ensconced within that very segment of society they rail against ... looking backwards has been a favourite sport for disaffected intellectuals for a long time, but actually moving backwards has not been so popular. (Edwards, 1985: 95, 97; my emphases)

Brutt-Griffler (2002), in her more recent critique of MLR, takes much the same position, arguing that individuals may well make their language choices on the basis of social class rather than ethnicity. As she observes:

If you make ethnicity, nationality, or minority status the unit of analysis, you can conclude that people would want to or have in their interest to maintain their mother tongue. If, on the contrary, you take class as the unit of analysis, their interest might dictate emphasis on access to 'dominant languages' . . (Brutt-Griffler, 2002: 225)

Edwards and Brutt-Griffler's arguments on language choice are representative here of the methodological individualism of rational choice theory (see Banton, 1980, 1987; Hechter, 1986, 1987). Methodological individualism assumes that groups are 'constituted from individual behaviour and are subject to continual change as individuals respond to changes in their circumstances' (Banton, 1987: 140). In this view, social relations become a form of market relations with individuals making rational choices about their ethnic alignment(s) solely on the basis of the social and material gain it will bring them. As Banton observes of this process, an individual will join in ethnic group mobilisation 'only when he expects the benefits of his participation to exceed the costs' (Banton, 1987: 136). When applied to the ethnic identity/language choice nexus, the cost/opportunity approach of rational choice theory would indicate clearly that particular languages do not define people, and may not be an important feature, or even a necessary one, in the construction of their identities, whether at the individual or collective levels. After all, how else is it possible to explain the exponentially increasing phenomenon of language shift?

These broad arguments on the contingency of language and identity are even more trenchantly promoted within the sociology of ethnicity and nationalism, where a social-constructivist view of ethnic and national identities has long held sway. In studies of ethnicity, for example, the prevailing consensus over the last 30 years has been that ethnicity is a largely constructed identity. In other words, 'primordial' accounts of ethnicity which argue that ethnicity is determined by particular objective cultural characteristics such as language, ancestry and history - what Barth (1969) has described as the 'cultural stuff' of ethnicity - is rejected out of hand as reified and essentialist. ${ }^{5}$ In its place is posited a 'situational' view of ethnicity, which is defined not by the specific characteristics of a particular identity itself, but by the way those characteristics are employed to distinguish one identity from another. On this view, ethnicity is about social relationships rather than specific cultural properties since 'we can assume no simple one-to-one relationship between ethnic units and cultural similarities or differences' (Barth, 1969: 14). Cultural attributes - such as a particular language, for example - are not significant in themselves since any one of a range of cultural 
properties could be used to fill the 'organisational vessel' of a particular ethnicity (Barth, 1969: 14; see also Eriksen, 1993).

Instead, it is the perceived usefulness of these cultural attributes in maintaining ethnic boundaries which is central. Cultural attributes only become significant as markers of ethnic identity when a group deems them to be necessary, or socially effective, for such purposes. Thus, particular cultural attributes may vary in salience, may be constructed or reconstructed, and may even be discarded by an ethnic group, depending on the particular sociohistorical circumstances of their interactions with other groups, and the need to maintain effectively the boundaries between them. It is these ethnic boundaries which determine in the end who is and who is not a member of a particular ethnic group, as well as designating which ethnic categories are available for individual identification at any given time and place (Nagel, 1994). In short, shared culture in this model is best understood as generated in and by the processes of ethnic boundary maintenance rather than the other way around (Jenkins, 1997).

This position also helps to explain why the particular attributes associated with an identity can change over time - as soon as the attribute in question is no longer seen as important in distinguishing the group from others, it may be changed or dropped. Language clearly falls within this category. Thus, Irish identity, while once distinguished by Irish Gaelic, is now distinguished primarily by a dialectal version of English (Edwards, 1994; May, 2001). Identity, in this conception, is dynamic and changing and, in the process, particular languages may come and go, depending on what is deemed necessary to maintain the wider identity in changing circumstances, and in relation to other groups.

In short, situational accounts of identity suggest there is nothing intrinsic to one's ethnic identity and thus specifically reject any significant or even any particular link between ethnicity and language. Of course, this position on ethnicity also accords broadly with the wider postmodernist rejection of any kind of monolithic identity - rather, all forms of identity are viewed as multiple, shifting, contingent, and invariably hybrid. On both counts, holding onto the idea of a link between a particular language and identity - as MLR advocates appear to do-seems not only irremediably passé, but unrealistic, since multiple identities, including multiple linguistic identities, are now the order of the day.

\section{The 'Utopian Dismissal'}

A closely related critique of MLR, particularly as it is expressed through the principles and presumptions of LE, concerns its inherent romanticism and utopianism. This critique of MLR might best be described as 'resigned language realism' - that as much as the process of language shift and loss is regrettable, there is little, if anything that can be done about it. Edwards $(1984,1985,1994,2001)$ has articulated this position most clearly over the years from within sociolinguistics (see also Brutt-Griffler, 2002).

The significance of this criticism is that one need not be an outright opponent of MLR to articulate it - indeed, one may even actively recognise, value and endorse the maintenance of linguistic diversity while holding to such a position. Edwards, for example, has consistently reiterated his 'own personal preference for a world rich in all sorts of diversities'. But as he immediately proceeds to 
observe: 'But preference alone, of course, is not the point' (Edwards, 2001: 239). When faced with the realpolitik of the often exponential shift and loss of their historically associated language(s), minority language groups (however heterogeneously defined), must, it seems, simply acquiesce to the 'march of progress'. In short, language revival in these circumstances is inherently artificial and bound to fail. As Edwards asserts: 'Cutting across all perceptual and terminological matters ... are the powerful facts of social life, facts recognised by even the most sanguine supporters of linguistic diversity. Even the strongest will-torevive may be dwarfed by societal pressures' (Edwards, 2001: 232). Or, as he has earlier observed:

language shift reflects sociopolitical change and this, given the historical perspective, absolutely dwarfs efforts made on behalf of language alone. This is not to say ... that language cannot serve a vital rallying purpose in nationalistic political movements, but it only does so when it retains some realistic degree of communicative function. (Edwards, 1984: 288)

On this basis, it is a profound error to think of language decline and loss as anything other than a symptom of widespread social confrontation between unequal forces, one that minority groups, and their languages, will always, inevitably lose (Edwards, 1994). Moreover, as Edwards' quotation in the section on essentialism above makes clear, not only are attempts at language revitalisation in these contexts Canute-like in their futility, they are also often instigated by minority elites, at the apparent expense of the interests and opinions of the wider group with respect to individual mobility and collective social and economic progress (see also the section on mobility below).

This 'utopian dismissal' of MLR is particularly evident in discussions of the LE movement, along with its biological/ecological metaphors and frame of reference. Language ecologists (see e.g. Harmon, 1995; Maffi, 2000, 2001; Mühlhäusler, 1996, 2000; Nettle \& Romaine, 2000) argue that the current parlous state of many of the world's languages is analogous to processes of biological/ ecological endangerment and extinction; indeed, is far greater than the threat of extinction facing animal and plant species. In other words, issues of biodiversity are broadly constructed as comparable to issues of linguistic diversity. Consequently, as with ecological loss, the loss of a language is seen as diminishing the world in both the short and longer term. In the short term, language loss results, clearly and simply, in a diminution of the linguistic gene pool. In the longer term, just as ecological destruction - such as deforestation of the Amazon - may not only affect those in the immediate vicinity, but have wider implications as a result of global climate change, so too might the current exponential loss of many of the world's languages actually be a prelude to wider linguistic catastrophe.

The parallels that are drawn by language ecologists between linguistic diversity and biodiversity have their merits, particularly in the clear resonances between the two processes. Thus, Steven Pinker observes that 'the wide-scale extinction of languages [currently underway] is reminiscent of the current (though less severe) wide-scale extinction of plant or animal species' (Pinker, 1995: 259). Likewise, James Crawford argues that each 'fall[s] victim to predators, changing environments, or more successful competitors', each is encroached 
upon by 'modern cultures abetted by new technologies' and each is threatened by 'destruction of lands and livelihoods; the spread of consumerism and other Western values' (Crawford, 1994: 5). Indeed, even critics acknowledge at least a metaphorical link here. As Edwards concedes, for example: 'in a world where opinion can be galvanised to save the whales, to preserve wetlands - or, indeed, to keep historic buildings from the wreckers' ball ... why should we not also try to stem language decline and prevent linguistic predation?' (Edwards, 2001: 233).

However, MLR sceptics such as Edwards also argue that LE tends to significantly overstate the links between linguistic and biological diversities, and particularly the suggestion that these are co-extensive and mutually supportive. This tendency is clearly demonstrated in the work of Skutnabb-Kangas (2000), for example (see also Harmon, 1995; Maffi, 2000, 2001). Brutt-Griffler also worries that LE 'may take its own hyperbole (the survival of biodiversity and perhaps, ultimately, the world is "correlated" and perhaps even causally related to [sic] linguistic diversity ...) literally and conclude that the world must be saved from its inevitable demise at whatever cost and at whomever's expense' (Brutt-Griffler, 2002: 224). By implication, such a move is not only impractical, but also potentially dangerous - an unnecessary attempt at 'social engineering'.

This argument returns, once again, to the perceived artificiality and impracticability, even advisability, of implementing these 'utopian wishes in the face of harsh realities' (Brutt-Griffler, 2002: 222). MLR may be well meaning, but its critics argue that it is not practically possible, and perhaps even actively counterproductive, to prop up cultural and language groups that are past their sell-by dates. After all, as Edwards observes, 'history is the graveyard of cultures' (Edwards, 2001: 235). And even if one accepts the social justice arguments that underpin these attempts to 'preserve' minority languages and cultures, there are invariably more important battles to fight. As Brutt-Griffler concludes: 'It would seem, at the least, naïve to believe that a world that does not guarantee the majority of its inhabitants basic human rights will be able to assure them those of the specifically linguistic variety' (Brutt-Griffler, 2002: 223). QED, or so it seems.

\section{The Problem of (Im)mobility}

A central trope of these arguments against LE, and by implication MLR more broadly, is the view that the ongoing retention of minority languages amounts to little more than cultural and linguistic stasis. In effect, critics of MLR often argue that the perpetuation of minority languages is actively regressive - foreclosing the process of 'linguistic modernisation' for minority groups and the possibilities of social mobility for its individual members. As Edwards pointedly asks: 'Is the implication that stasis is the price of ethnolinguistic continuity? If so, history suggests it is a price higher than most have been willing to pay' (Edwards, 2001: 237).

Many critics of MLR repeatedly return to this point. In effect, minority-language advocates are criticised for consigning, or ghettoising, minority-language communities within the confines of a language that does not have a wider use, thus constraining their social mobility (see also Barry, 2000; Ladefoged, 1992; Schlesinger, 1992). Little wonder, such critics observe, that 
many within the linguistic minority itself choose to ignore the pleas of minority language 'activists' and / or elites, and instead 'exit' the linguistic group by learning another (invariably, more dominant) language. It is one thing, after all, to proclaim the merits of retaining a particular language for identity purposes, quite another to have to live a life delimited by it - foreclosing the opportunity for mobility in the process. On this view, collective modernisation and individual mobility are best served - indeed, are only served - by access to dominant languages, particularly English (cf. Brutt-Griffler, 2002).

The logic of this argument can be broadly summarised as follows:

- Majority languages are lauded for their 'instrumental' value, while minority languages are accorded 'sentimental' value, but are broadly constructed as obstacles to social mobility and progress.

- Learning a majority language will thus provide individuals with greater economic and social mobility.

- Learning a minority language, while (possibly) important for reasons of cultural continuity, delimits an individual's mobility; in its strongest terms, this might amount to actual 'ghettoisation'.

- If minority-language speakers are 'sensible' they will opt for mobility and modernity via the majority language.

- Whatever decision is made, the choice between opting for a majority or minority language is constructed as oppositional, even mutually exclusive.

This broad underlying philosophy was a prominent feature of early attempts at language planning and policy (LPP) in the 1960s and1970s. Status language concerns at this time focused in particular on establishing 'stable' diglossic language contexts in which majority languages (usually, ex-colonial languages, and most often English and French) were promoted as public languages of the state. ${ }^{6}$ If promoted at all, local languages - minority languages, in effect - were seen as being limited to private, familial language domains. While concern was often expressed for the ongoing maintenance of minority languages, the principal emphasis of early LPP was on the establishment and promotion of 'unifying' majority (national) languages in postcolonial contexts, along the lines of those in Western, developed contexts (see, for example, Fishman, 1968a, 1968b, 1968c; Fox, 1975; Rubin \& Jernudd, 1971).

The necessity of 'linguistic modernisation', and the related normative ascendancy of majority languages, were thus simply assumed, even championed, by early advocates of LPP, and all other languages were compared in relation to them. This is highlighted by the various language typologies developed at the time, such as Kloss (1968), which attempted to rank languages in relation to their relative 'suitability' for national development, that is, modernisation. Along the way, majority languages were consistently constructed as languages of 'wider communication' while minority languages were viewed, at best, as (merely) carriers of 'tradition' or 'historical identity' and, at worst, as actively detrimental to their speakers and their wider mobility (see May, 2005).

These views remain just as prevalent today. As critics of MLR would have it, it seems that majority languages are those (and only those) that are the most instrumentally useful. Simply put, it is possible to accomplish a lot more in and by a majority language. This is a difficult argument to refute and may well explain 
why the social justice arguments underlying MLR seem to be simply ignored in the realpolitik of language shift and loss (see also the previous section). After all, democratic and justice sentiments are all very well, but they are not necessarily going to increase one's standard of living, or provide a useful, upwardly mobile education for one's children. Indeed, opponents of MLR have gone so far as to argue that to opt for an education in a minority language in the face of this critique is a sign of irresponsible parenthood, even a form of 'child abuse'. This is perhaps best exemplified in a 1995 court case in Amarillo, Texas, where, in a dispute over the custody of a child, a judge ordered a mother not to speak Spanish to her child at home on these very grounds:

If she starts [school] with the other children and cannot even speak the language that the teachers and others speak, and she's a full-blooded American citizen, you're abusing that child ... Now get this straight: you start speaking English to that child, because if she doesn't do good in school, then I can remove her because it's not in her best interests to be ignorant. (Cited in de Varennes, 1996a: 165-6)

However much one might disagree with these sentiments - and certainly, the only ignorance demonstrated here appears to be the judge's - such views remain widely held. The US English Only movement, for example, likewise argues that English is essential for social mobility in US society, or rather, a lack of English is seen to consign one inevitably to the social and economic margins. As Linda Chávez, a former President of US English, has argued: 'Hispanics who learn English will be able to avail themselves of opportunities. Those who do not will be relegated to second class citizenship' (cited in Crawford 1992: 172). Guy Wright, a prominent media supporter of English Only policies, takes a similar line in a 1983 editorial in the San Francisco Examiner, asserting that 'the individual who fails to learn English is condemned to semi-citizenship, condemned to low pay, condemned to remain in the ghetto' (cited in Secada \& Lightfoot, 1993: 47). A more recent example can be found in US English advertising in 1998: 'Deprive a child of an education. Handicap a young life outside the classroom. Restrict social mobility. If it came at the hand of a parent it would be called child abuse. At the hand of our schools ... it's called "bilingual education"' (see Dicker, 2000:53).

This position is also broadly endorsed by significant academic commentators within social and political theory. Thus, Thomas Pogge, a prominent US political theorist, could argue recently that minority parents who opted for an education for their children in a minority language may be 'perpetuating a cultural community irrespective of whether this benefits the children concerned' (Pogge, 2003: 118). In other words, it is illiberal and injurious for parents to 'consign' their children to a minority-language education. Two other political theorists, David Laitin and Rob Reich, argue much the same position when they assert that 'forcing' bilingual education on children will curtail 'their opportunities to learn the language of some broader societal culture' (Laitin \& Reich, 2003: 92). Relatedly, they fret that these 'individuals have no influence over the language of their parents, yet their parents' language if it is a minority one . . constrains social mobility'. As a result, 'those who speak a minority (or dominated) language are more likely to stand permanently on the lower-rungs of the socio-economic ladder' (Laitin \& Reich, 2003: 92; my emphasis). Indeed, they proceed to observe 
that if minority individuals are foolish enough to perpetuate the speaking of a minority language, then they can simply be regarded as 'happy slaves', having no one else to blame but themselves for their subsequent limited social mobility.

In the light of these trenchant attitudes in both political and academic commentary, it is perhaps not surprising that arguments for MLR appear to be making so little headway. Whatever the cultural 'benefits', and returning to the issue of rational choice, it seems that the only 'responsible' option open to minority-language speakers is to educate their children in the majority language. Thus, a central tenet of MLR - minority-language education, or mother-tongue education (see May, 2001; Skutnabb-Kangas, 2000) - is immediately, perhaps fatally, undermined, at least for MLR critics. Not surprisingly, their solution is to return to the status quo ante of educational assimilation for minority groups, given that this would appear to be demonstrably in the 'best' interests of minority children. For example, Pogge (2003), in his discussion of the merits of a US public education in English versus a more multilingual approach, clearly equates the former with the 'best interests of the child', in relation both to developing 'fluency in English' and in 'enabling all students to participate fully in US society' that is, individual mobility and collective integration.

The three key concerns just outlined - essentialism, utopianism and mobility present a considerable challenge to the ongoing development and extension of language planning for MLR - if only in the regularity with which they are invoked. While some of the points that are made are valid, as I will make clear, these arguments also exhibit considerable weaknesses of their own - not least in their tendency to hyperbole, and in relation to a number of fundamental misconceptions, inconsistencies and contradictions. It is to the latter that I now want to turn.

\section{Avoiding Essentialism}

With respect to the charges of essentialism levelled against MLR, one first needs to acknowledge that situational accounts of ethnicity, and of the language-identity link, are broadly right. Language clearly is a contingent marker of ethnic (and national) identity and adopting any other position involves, inevitably, an essentialised and reified view of the language-identity link (see May, 2001 for an extended discussion here). Indeed, I have argued elsewhere (see especially, May, 2000a) that one of the key weaknesses of both the LE and LHR movements has been a tendency to assume the collective nature of linguistic minority groups as given, the collective aims of linguistic minority groups as uniform, and the notion of collective rights as unproblematic. Thus Skutnabb-Kangas and Phillipson (1995) argue that the notion of linguistic human rights is reflected at the level of linguistic communities by the collective rights of peoples to maintain their ethnolinguistic identity and difference from the dominant society and its language (see also Skutnabb-Kangas, 2000). I agree with this in principle, but the way the argument is often formulated assumes that the linguistic community in question is easily definable in the first place - or, rather that all members of this group are (or will want to be) principally identified and identifiable by their language. And yet, as critics such as Brutt-Griffler (2002) rightly argue, this simply cannot be assumed, not least because of 
processes of language shift and loss which may already have led many group members to abandon the minority language in question and/or any identification they may have had with it. This, in turn, highlights the essentially contested nature of 'collective' aims. Even if some level of collective consensus is reached about language, or indeed any other aspect of group life - and this in itself is no easy task - there will always be individuals who will choose to dissent from these conclusions, as MLR critics are quick to point out (see e.g. Bentahila \& Davies, 1993; Edwards, 1985, 1994). This common disjuncture between 'individual' and 'collective' aims immediately problematises the legitimacy of any claim to a group-based minority language right, whatever its social and political merits.

So, if advocates of MLR are ever to carry the day, they must address more adequately the complexities - and, at times, contradictions - that surround debates on individual and collective identities, and their associated rights' claims. Crucially, this involves critically examining, rather than simply assuming, the question of the link between language and identity. The contingent nature of linguistic identity - as one of many (sometimes) competing identities available to the minority language speaker - also needs to be specifically acknowledged and accommodated (see also my discussion of Bourdieu below).

Accepting the contingency of the language and identity link, however, does not fatally undermine arguments for MLR, as critics are often wont to suggest. Indeed, as I will argue, it can actually strengthen these arguments considerably. For a start, it brings MLR arguments into line with wider constructivist social and political analysis, and not before time. While a specific language may well be identified as a significant cultural marker of a particular ethnic group, there is no inevitable correspondence between language and ethnicity. In effect, linguistic differences do not always correspond to ethnic ones - membership of an ethnic group does not necessarily entail an ongoing association with a particular language, either for individual members or for the group itself. Likewise, more than one ethnic group can share the same language while continuing without difficulty to maintain their own distinct ethnic (and national) identities. Indeed, even where language is regarded as a central feature of ethnic identity, it is the diacritical significance attached to language which is considered crucial, not the actual language itself (cf. Barth, 1969). Moreover, languages, along with other cultural attributes, vary in their salience to ethnicity both within and between historical periods, and this also helps to explain why the association of particular languages with particular ethnic groups may well change over time. As the 19th-century social commentator Ernest Renan has argued, language may well be an important attribute of collective identities but it is certainly not the only one, nor is it even essential: 'language may invite us to unite but it does not compel us to do so' (Renan, 1990: 16).

However, to say that language is not an inevitable feature of identity is not the same as saying it is unimportant. Yet many constructivist commentators, including many MLR critics, in (rightly) assuming the former position have also (wrongly) assumed the latter. In other words, they assume that because language is merely a contingent factor of identity it cannot therefore (ever) be a significant or constitutive factor of identity. As a result, contingency is elided with unimportance or peripheralism - an additional move that is neither necessary nor warranted. 
Indeed, this position is extremely problematic, not least because of the considerable evidence 'in the real world' (something MLR critics frequently invoke to support their own arguments) that suggests that, while language may not be a determining feature of ethnic identity, it remains nonetheless a significant one in many instances. Or to put it another way, it simply does not reflect adequately, let alone explain, the heightened saliency of language issues in many historical and contemporary political conflicts, particularly at the intrastate level (see Blommaert, 1996, 1999; May, 2001; Weinstein, 1983, 1990). In these conflicts, particular languages clearly are for many people an important and constitutive factor of their individual, and at times, collective identities. This is so, even when holding onto such languages has specific negative social and political consequences for their speakers, most often via active discrimination and / or oppression. Catalans and Basques in Franco's Spain, or the ongoing plight of the Kurds in Turkey, are but two examples - there are numerous others.

The will to maintain historically associated languages in often highly oppressive contexts also problematises in turn the notion of 'rational choice'. The assertion that speakers only make decisions on purely instrumentalist grounds, or at least that instrumental reasons are the only valid or rational choice available to minority-language speakers, is at best one-sided, and at worst simply wrong. Ethnic groups may hold on tenaciously to a particular language precisely because greater functionality in another language is not, in itself, enough. Or if it is, the price for achieving it via that dominant language - given that it is usually at the specific expense of the other language - may be regarded as simply too high.

The apparent contradiction between the detachability of language and identity, and the passions that particular languages may still invoke, is alluded to by Benedict Anderson in his highly influential account Imagined Communities, where he avers of language:

What the eye is to the lover - that particular, ordinary eye he or she is born with - language - whatever language history has made his or her mother tongue - is to the patriot. Through that language, encountered at mother's knee and parted only at the grave, pasts are restored, fellowships are imagined, and futures dreamed. (Anderson, 1991: 154)

And yet Anderson is also the first to reject any suggestion of some kind of primordial status to language. It is always a mistake, he argues, to treat languages in the way that certain ethnic and nationalist ideologues treat them, 'as emblems of nation-ness, like flags, costumes, folk dances and the rest'. Much the more important aspect of language is 'its capacity for generating imagined communities, building in effect particular solidarities' (Anderson, 1991: 133; emphases in original). The sociolinguist, Monica Heller, makes a similar point when she discusses the interrelationship between language and ethnic identity in a French immersion school in Toronto, Canada:

Language use is ... involved in the formation of ethnicidentity in two ways. First, it constrains access to participation in activities and to formation of social relationships. Thus at a basic level language use is central to the formation of group boundaries. Second, as children spend more and more time together 
they share experience, and language is a central means of making sense out of that shared experience. (Heller, 1987: 199; my emphasis)

Language, as a communally shared good, serves an important boundary-marking function (Tabouret-Keller, 1997). After all, being unable to speak a particular language places immediate restrictions on one's ability to communicate - and, by extension, identify - with those who speak that language and any ethnic and/or national identities with which it is associated. This process of demarcation may be more salient for minority groups since such groups are likely to be more conscious of the need for clear linguistic boundaries in relation to a surrounding dominant language and culture. The usefulness of linguistic demarcation may also thus help to explain why language often has a heightened sense of saliency in relation to identity when its role as only one of a number of cultural markers might suggest otherwise. Moreover, to the extent that language boundaries are employed as a demarcating feature of identity, then a decreasing emphasis on, or a blurring of, these boundaries would be regarded as a threat to a group's existence (Khleif, 1979).

In theory then, language may well be just one of many markers of identity. In practice, it is often much more than that. Indeed, this should not be surprising since the link between language and identity encompasses both significant cultural and political dimensions. The cultural dimension is demonstrated by the fact that one's individual and social identities, and their complex interconnections, are inevitably mediated in and through particular languages. The political dimension is significant to the extent that those languages come to be formally (and informally) associated with particular ethnic and national identities. These interconnections also help to explain why, as Fishman (1997) argues, a 'detached' scientific view of the link between language and identity may fail to capture the degree to which language is experienced as vital by those who speak it. It may also significantly understate the role that language plays in social organisation and mobilisation. The 'shibboleth of language', as Toynbee (1953) coined it, still holds much sway.

Another way to explain these apparent contradictions is actually to rethink the whole primordial/situational dichotomy of ethnicity within sociology and anthropology (see the discussion of essentialism above). Indeed, there is an increasing consensus among writers on ethnicity that this dichotomy is in the end unhelpful and unnecessary and that one can, and should, combine elements of the two (see May, 2001 for an extended discussion; see also Fenton, 1999; Jenkins, 1997). Adopting this more dynamic, dialectical position on ethnicity helps to explain, on the one hand, why the cultural and linguistic characteristics of ethnic groups may not (indeed, almost certainly do not) define or delimit such groups, and yet on the other hand they also often continue to hold considerable purchase for their members. Bourdieu's notion of 'habitus' perhaps best captures this dual emphasis since 'habitus' refers to a set of embodied meanings that do not determine how individuals and groups might act, but nonetheless constitutes a powerful frame of reference, which influences and shapes, at least to some degree, how the world is seen (see Bourdieu, 1984, 1990a, 1990b; Bourdieu \& Passeron, 1990; Bourdieu \& Wacquant, 1992). In particular, the four key dimensions of habitus highlighted in Bourdieu's work - embodiment, agency, the 
interplay between past and present, and the interrelationship between collective and individual trajectories - provide a useful means of examining both the continuing purchase and malleability of ethnicity, and the particular languages associated with them, at any given time and place (see May, 2001 for an extended discussion).

For Bourdieu, habitus is not simply about ideology, attitude or perception, it is a set of embodied dispositions - or ways of viewing, and living in the world. This set of dispositions - what Bourdieu would call 'bodily hexis' - operates most often at the level of the unconscious and the mundane and, in the case of ethnicity, often involves language use. Indeed, linguistic habitus, in Bourdieu's (1991) terms, is a subset of the dispositions which comprise the habitus: it is that set of dispositions acquired in the course of learning to speak in particular social and cultural contexts. The key point for Bourdieu is that ethnic attitudes and practices, including language use, are usually lived out implicitly as a result of historical and customary practice. As such, they may provide the parameters of social action for many. However, they are also never limited to those parameters, and may change over time, both internally, as a result of their ongoing use, and externally in relation to wider economic, social and political influences. This helps to explain why languages that have been traditionally associated with a particular ethnicity can continue to hold such importance for particular ethnic identities. However, it can also explain why such languages can equally come to be replaced over time with other languages.

This ongoing tension between continuity and change is further explained via Bourdieu's other key dimensions of habitus. For example, in relation to the complex interaction between agency and structure, Bourdieu argues that habitus does not determine individual behaviour. A range of choices, or strategic practices, is presented to individuals within the internalised framework of the habitus. Moreover, these practices, based on the intuitions of the practical sense, orient rather than strictly determine action. Choice is thus at the heart of habitus. However, not all choices are possible. As Bourdieu observes, 'habitus, like every "art of inventing" ... makes it possible to produce an infinite number of practices that are relatively unpredictable (like the corresponding situations) but [which are] also limited in their diversity' (Bourdieu, 1990b: 55). These limits are set by the historically and socially situated conditions of the habitus' production; what Bourdieu terms both 'a conditioned and conditional freedom' (Bourdieu, 1990b: 55). In short, improbable practices, or practices viewed as antithetical to the mores of a particular group, are rejected as unthinkable. Concomitantly, only a particular range of possible practices is considered, although this range of possibilities may evolve and change over time in relation to changing circumstances. Thus, Bourdieu posits that individuals and groups operate strategically within the constraints of a particular habitus, but also that they react to changing external conditions; economic, technological and political (Harker, 1984, 1990; Harker \& May, 1993; May, 1999a).

This recursive position allows Bourdieu to argue that the habitus, including linguistic habitus, is both a product of early socialisation, yet is also continually modified by individuals' experience of the outside world (Di Maggio, 1979). Within this complex interplay of past and present experience - the third key dimension of Bourdieu's work highlighted here - habitus can be said to reflect 
the social, cultural and linguistic position in which it was constructed, while also allowing for its transformation in current circumstances. However, the possibilities of action in most instances will tend to reproduce rather than transform the limits of possibility delineated by the social group. This is because habitus, as a product of history, ensures the active presence of past experiences, which tend also to normalise particular cultural and linguistic practices, and their constancy, over time (Harker \& May, 1993). Nonetheless, this tendency towards reproduction of group mores and practices does not detract from the potential for transformation and change, as evidenced in the linguistic context by language shift.

The fourth element of habitus - the interrelationship between individual action and group mores - also reflects this tension. In many instances, individual practices, including language practices, will conform to those of the group since, as Bourdieu argues, 'the practices of the members of the same group . . . are always more and better harmonised than the agents know or wish' (Bourdieu, 1990b: 59). Yet Bourdieu also recognises the potential for divergence between individual and collective trajectories. In effect, habitus within, as well as between, social groups differs to the extent that the details of individuals' social trajectories diverge from one another.

In addition, habitus is also extremely pertinent to a discussion of language and ethnicity because it is employed by Bourdieu principally in order to explore inequalities in power between dominant and subordinate groups. As Bourdieu argues, the individual and collective habitus of the former is invariably constituted as cultural capital - that is, recognised as socially valuable - whereas the habitus of the latter is not. This has obvious parallels with the negative, and commonly expressed views of ethnic minority cultures and practices (including the speaking of a minority language) as regressive and 'premodern'. These views - which Lukes (1996) has aptly described as the product of 'ascriptive humiliation' - are expressed predominantly by majority group members. However, they are also expressed by minority group members themselves, usually as the end result of a process of negative internalisation. Bourdieu (1991) terms the process by which the latter is achieved as 'méconnaissance' or 'misrecognition' and its inevitably deleterious consequences as 'symbolic violence'. Consequently, the habitus of ethnic minority individuals and groups, including their linguistic habitus, tends to be specifically marginalised and devalued, both as a legitimate means of identity, and for their apparent lack of 'relevance' to the 'modern world'.

I have discussed Bourdieu at some length because the notion of habitus usefully highlights, and specifically attempts to bridge, central issues of linguistic continuity and change for minority-language speakers. In contrast, critics of MLR tend to construct a far more bipolar and teleological account of language and identity, arguing for the inevitability of language shift on the basis of wider historical processes of change, while at the same time ignoring the clear and ongoing cultural and linguistic continuities evident among many minority-language groups. This also begs the question, discussed further below, as to why cultural and linguistic change and adaptation should always be unidirectional-from a minority language/ culture to a majority one? The short answer is it need not and, for reasons that will soon become apparent, to suggest otherwise is both inconsistent and unjust. 


\section{Promoting Dialogism}

Bourdieu's notion of habitus usefully highlights the fact that cultural and linguistic continuity and change are always intrinsically interconnected. On this basis, we can reject the reductionist account of MLR critics who invariably cast linguistic continuity and change for minority groups as polar opposites - as incompatible, or even irreconcilable imperatives. I use the term 'imperatives' deliberately here since it also accurately describes the notion of uncontrollable volition, under the guise of 'linguistic modernisation', which so often underpins much of the rhetorical framework of these critics. There is, it seems, very little room for agency - except of a prescribed kind, the renunciation of one's historically associated language(s) - in critiques of MLR. One must simply get with the (new) linguistic programme, or be left behind. As has been seen, this in turn casts linguistic continuity ineluctably with stasis, and linguistic shift or change with 'modernisation' or 'development'.

This is simply wrong (and wrongheaded). There is nothing to preclude ongoing cultural and linguistic adaptation and change, including access to dominant languages, for minority group speakers who choose to continue to speak their historically associated language(s). From a Bourdieuian perspective, what is involved is a language continuum, a dialogical relationship between linguistic continuity and change, rather than a dichotomous one. Such a position makes it possible to question and critique the necessity of language shift for minority groups, an underlying principle of the arguments of MLR critics, while acknowledging the significant social and political forces pressing for linguistic change. At the same time, it allows one to avoid delegitimising, by definition, countervailing forces for ongoing linguistic continuity. Wanting to maintain links to the latter, while necessarily engaging with the former, is not inherently romanticist and / or antediluvian as MLR critics assert, but rather a considered response by minority-language speakers to the demands, opportunities, and obligations of each. After all, as the political theorist Will Kymlicka observes: 'leaving one's [language and] culture, while possible, is best seen as renouncing something to which one is reasonably entitled' (Kymlicka, 1995: 90). Even Brutt-Griffler (2002), in her trenchant critique of MLR, does eventually concede that language complementarity rather than language replacement is a possible positive outcome of MLR, although she then unconvincingly suggests that if minority-language speakers cannot have access to English as a first language (reverting again to the necessity of language shift), this undermines any meaningful notion of complementarity. Again, unless the dominant language dominates, it seems, justice and opportunity cannot be achieved. This is a significant difference in emphasis that MLR advocates and their critics will continue to debate forcefully, but my point is that the presumption in favour of a majority or dominant language is itself open to significant question (see 'rethinking mobility' below).

Having said that, critics of MLR such as Edwards and Brutt-Griffler do have a point about the limits of LE arguments. I have argued elsewhere (May, 2000a; see also Blommaert, 2001) that while the connections drawn between biological and linguistic ecology do have some merits, they also have significant limitations, not least because such arguments actually reinforce, albeit unwittingly, the inevitability of the evolutionary change that they are protesting about. This is because 
while biological/ecological metaphors are useful in highlighting the scale and seriousness of the potential loss of languages to the world, they also contribute, ironically, to the equanimity with which potential language loss on such a scale is usually greeted. In effect, such metaphors reinforce, by implication, a widely held view that language loss is an inevitable part of the cycle of social and linguistic evolution. Thus, one could view the loss or death of a language as simply a failure on its part, or its speakers, to compete adequately in the modern world where, of course, only the fittest languages can (and should) survive (see e.g. Ladefoged, 1992).

In this respect, the often-symbiotic relationship between LE and MLR might prove to be actively counterproductive, not least because what tends to be lost from sight when an LE approach is taken to the question of language loss - or linguistic genocide, as Skutnabb-Kangas (2000) would have it ${ }^{7}$ - are the wider social and political power relations which inevitably underlie it. This is where a more overtly sociohistorical/ sociopolitical analysis of language proves far more productive than a biological/historical one, particularly in its ability to examine the wider processes of social, cultural and political displacement that inevitably attend language shift and loss. ${ }^{8}$

Adopting this sociohistorical/sociopolitical approach also makes it possible to critique a number of highly problematic assumptions underpinning arguments against MLR. One is the regular invocation by critics that minority elites who support MLR are unrepresentative and / or opportunistic, actively working against the wider interests of their constituents. The perpetuation of social class (and economic) inequalities is a potential characteristic of elite involvement, as Brutt-Griffler (2002) rightly highlights, but it is not limited, of course, to minority groups. Similarly, the question of an 'unrepresentative' minority leadership is largely a red herring - merely a useful stick, in effect, with which to beat proponents of minority language rights. ${ }^{9}$ All groups, being heterogeneous by definition, speak with more than one voice. Thus, it is a reductio ad absurdam to argue, as many MLR critics do (see e.g. Edwards, 1985, 1994; Laitin \& Reich, 2003), that the presence of internal differences within minority groups over the question of minority language(s), or even active dissent, somehow negates the legitimacy of minority-language claims.

The same criticism can apply to the accusation of 'social engineering' or the 'politically motivated' actions of MLR proponents. In this respect, MLR advocates are often accused of (unnecessarily) introducing a moral(ist) dimension in their attempts to promote minority languages. Edwards regularly makes this observation, and the implication underlying it, commenting recently, for example, that: 'Arguments for maintenance, revival and language diversity in general often involve a moral component' (Edwards, 2001: 233). The problem with this analysis is that it conveniently ignores the fact that all positions that are taken on language and minority rights involve a moral dimension, reflecting the particular values and ideologies of their exponents (cf. Blommaert, 1999; Woolard, 1998). Ideology and social engineering are not the sole preserve of MLR proponents, although they are often painted as such. Moreover, if the assumption that the sociopolitical dominates the linguistic when it comes to questions of language shift is accepted, as critics of MLR assert, then it is necessary also to accept that arguments both for and against any language shift are inherently 
political. On this basis, Edwards' arguments, and their like, simply represent a particular value judgement - a judgement that equates minority-language loss, and language shift to a majority language, ineluctably with 'progress' and 'modernity' - while at the same time actively foreclosing alternative possibilities (see the section on rethinking mobility below).

\section{Rethinking Mobility}

This brings me to the final response: addressing and answering the question of language and mobility. What I want to suggest here is that the presumptions and assumptions that equate linguistic mobility solely with majority languages and / or with linguistic modernisation are themselves extremely problematic.

For a start, this position separates the instrumental and identity aspects of language. On this view, minority languages may be important for identity but have no instrumental value, while majority languages are construed as primarily instrumental with little or no identity value. This can be seen in the allied notions of majority languages as 'vehicles' of modernity, and minority languages as (merely) 'carriers' of identity. And yet it is clear that all language(s) embody and accomplish both identity and instrumental functions for those who speak them. Where particular languages - especially majority / minority languages - differ is in the degree to which they can accomplish each of these functions, and this in turn is dependent on the social and political (not linguistic) constraints in which they operate (Carens, 2000). Thus, in the case of minority languages, their instrumental value is often constrained by wider social and political processes that have resulted in the privileging of other language varieties in the public realm. Meanwhile, for majority languages, the identity characteristics of the language are clearly important for their speakers, but often become subsumed within and normalised by the instrumental functions that these languages fulfil. This is particularly apparent with respect to monolingual speakers of English, given the position of English as the current world language.

On this basis, it can be argued that the limited instrumentality of particular minority languages at any given time need not always remain so. Indeed, if the minority position of a language is the specific product of wider historical and contemporary social and political relationships, changing these wider relationships positively with respect to a minority language should bring about both enhanced instrumentality for the language in question, and increased mobility for its speakers. There is nothing 'impractical' or 'utopian' about this. Indeed, this can be seen to be occurring currently in Wales and Catalunya, with the emergence of formerly subjugated languages into the public domain (May, 2000b, 2002).

In the case of language planning and policy in Wales, for example, the 1993 Welsh Language Act (Mesur yr Iaith Gymraeg) treated Welsh for the first time as having 'a basis of equality' with English within Wales, although it qualifies this equality as being that which is appropriate within the circumstances and 'reasonably practicable'. To this end, the Act provides for the right to use Welsh in courts, given suitable notice, and also states that public documents in Welsh should carry the same legal weight as those in English. However, perhaps its most significant feature is the statutory recognition provided to Bwrdd yr Iaith 
Gymraeg (the Welsh Language Board). Under the Act's aegis, the Bwrdd yr Iaith is authorised not only to promote and facilitate the use of the Welsh language but also to ensure its adoption within the public sector. The latter is to be achieved via formal language schemes provided by public organisations to the Board. These schemes are to specify the measures each organisation aims to take in order to provide effective bilingual public services in Wales. Again, there is the caveat invoked that such bilingual services will be provided 'so far as is both appropriate in the circumstances and reasonably practical'. However, as the subsequent Draft Guidelines for implementation of the Act outline, it is Bwrdd yr Iaith, crucially, not the organisations, which determines the parameters of reasonableness and practicality: 'It will not be acceptable for those preparing schemes to adopt a highly subjective and restricted view of what is appropriate in their circumstances or reasonably practicable' (Welsh Language Board, 1995: 6). Likewise, the Draft Guidelines stipulate that organisations should not rely on the current demand for services in Welsh as a basis for their schemes, on the premise that once more effective bilingual services become available so too will demand increase:

It is acknowledged that, in the past, many Welsh speakers turned to English in dealing with public organizations because they were not certain what services were available in Welsh. Some were also concerned that using Welsh could lead to delay or a lower standard of service. Therefore, whatever their experience to date, organizations should plan for an increase in demand and respond accordingly. (Welsh Language Board, 1995: 5; my emphasis)

The end result envisaged for each organisation is that public service provision through Welsh should be a natural, integral part of the planning and delivery of that service - that is, that Welsh can be as instrumentally useful for accessing all public services in Wales, as English.

Providing Welsh speakers with the choice of using Welsh as a public as well as a private language also usefully highlights for majority-language speakers (English speakers in the Welsh context) the combined identity/instrumental dimensions of all languages. If majority-language speakers are made to realise that their own languages fulfil important identity functions for them, both as individuals and as a group, they may in turn be slightly more reluctant to require minority-language speakers to dispense with theirs. Or to put it another way, if majority languages do provide their speakers with particular and often significant individual and collective forms of linguistic identity, as they clearly do, it seems unjust to deny these same benefits, out of court, to minority-language speakers.

That said, convincing majority-language speakers of the merits of MLR - what I have elsewhere discussed, following Grin (1995), as the problem of tolerability (May, 2000a, 2002) - remains a formidable task. A good place to start though is by pointing out some key misconceptions, as well as some obvious inconsistencies, in arguments against the utility, or lack thereof, of minority languages. I saw above, for example, the apocalyptic assertion that the promotion of bilingual education in the US would result in the inevitable ghettoisation of minoritylanguage students. As the political theorists Laitin and Reich concluded, 
those who continue to 'speak a minority (or dominated) language are more likely to stand permanently on the lower-rungs of the socio-economic ladder' and, as such, can be regarded as nothing more than 'happy slaves' (Laitin \& Reich, 2003: 92).

Setting aside the offensive paternalism of these remarks, the principal problem with the construction of this general argument is that it confuses cause and effect. It is clear that a lack of knowledge of a dominant language (English in the US context) will limit the options for those who do not speak that language variety. But that is not the only reason why such individuals might find themselves 'permanently on the lower-rungs of the socio-economic ladder'. This is so because arguments asserting that English is the key to social mobility, and conversely that its lack is the principal cause of social and economic marginalisation, conveniently overlook the central question of the wider structural disadvantages facing minority-language speakers, not least racism and discrimination. After all, in the USA, African Americans have been speaking English for 200 years and yet many still find themselves relegated to urban ghettos (Macedo, 1994). Likewise, English is almost as inoperative with respect to Hispanic social mobility in the USA as it is with respect to black social mobility. Twenty-five per cent of Hispanics currently live at or below the poverty line, a rate that is at least twice as high as the proportion of Hispanics who are not English speaking (Garcia, 1995; San Miguel \& Valencia, 1998).

Even when language is a factor, it may have as much, or more to do with the linguistic intolerance of the state, judiciary, or the workplace, than with the individuals concerned. This was clearly demonstrated in the Amarillo, Texas, court ruling, discussed earlier. It is also clearly demonstrated in the US context by the proscription of Spanish in many US workplaces, as seen, for example, in Garcia v. Spun Steak (1993). ${ }^{10}$

Then there is the problem of consistency. On the one hand, there is the construction of minority languages in these accounts as essentially antiinstrumental, as merely 'carriers' of 'identity', and yet on the other, when such languages do become useful instrumentally in the public realm, this is held against them as well! This overt double standard clearly applies to the Welsh-language case discussed earlier. For example, the political theorist Brian Barry, a trenchant critic of MLR and of multiculturalism more generally, specifically bemoans the labour market advantages of those with an educational qualification in the Welsh language because local authorities increasingly require knowledge of Welsh as a condition of employment (see Barry, 2000: 105-6). This is rich indeed, given that these exact same arguments are made without apology by Barry, and other MLR critics, on behalf of majority languages, particularly English. They simply cannot have it both ways - deriding minority languages for their lack of utility, and then opposing their utility when it proves to be politically inconvenient.

Barry also complains that Welsh-language requirements in education may amount to 'discrimination' against (monolingual) English speakers, delimiting their individual language rights. As he laments:

it has to be recognized that the great majority of the people of Wales do not speak Welsh at home, and for them learning Welsh in school from scratch is 
in direct competition for time with learning a major foreign language. It is therefore scarcely surprising that compulsory instruction in Welsh schools has aroused opposition from English-speaking parents. (Barry, 2000: 105; my emphasis)

However, cries of discrimination on this basis are similarly spurious, since the assertion is not based on any perceived threat to the majority-language, but rather upon the implicit, sometimes explicit, wish of majority language speakers to remain monolingual (May, 2000b). Certainly, the requirement to be bilingual in English and Welsh does not at any point threaten the individual's ability and scope to use English within Wales; quite the reverse, in fact, since English remains dominant in all language domains. Indeed, this is true in almost all cases where a minority language is formalised in the public realm since what is being promoted is not a new monolingualism in the minority language-indeed, this is usually neither politically nor practically sustainable - but merely the possibility of bilingualism or multilingualism. In other words, the majority-language is not generally being precluded from the public realm, nor proscribed at the individual level, nor are majority-language speakers actually penalised for speaking their language. ${ }^{11}$ Rather, monolingual majority-language speakers are being asked to accommodate to the ongoing presence of a minority language and to recognise its status as an additional language of the state - a process that I have elsewhere described as 'mutual accommodation' (May, 2001).

Levelling charges of discrimination with regard to minority-language requirements, as in the Welsh case, can be seen in this light, rather than as a legitimate, or a sustainable argument. Likewise, returning to the argument of utility, being able to speak Welsh within Wales (whether as a first or second language) is surely more immediately useful than speaking another language, particularly if Welsh is already established in the public domain. If it is deemed not to be useful, this is simply a particular value judgement about the perceived (low) status of Welsh, a position seen clearly in Barry's preference for 'major foreign languages'. As I have consistently argued, this bipolar construction of majority/minority languages is neither necessary nor warranted. It is also far from disinterested, although it is often presented as such. Rather, it is a specific sociopolitical 'move' in the contest over language rights - a move that aims to secure the linguistic status quo ante for majority-language speakers, should the social and political dominance of their language ever appear to be threatened by the 'intrusion' of a minority language into the public realm.

This leads directly to another regular inconsistency in critiques of MLR with respect to minority and majority languages. On the one hand, critics of MLR rail against its potentially closed and static tendencies, highly problematic though these assumptions often are. And yet these same critics often adopt - at least implicitly, and sometimes explicitly - an inviolate conception of dominant languages, particularly within nation-states. What can be seen here, in effect, is exactly the thinking that MLR advocates are supposedly being criticised for - a conception of language (in this case, the majoritarian language of the state) as pre-given, closed, unchanging, unable to deal with interaction, engagement and reciprocity with other languages in an ongoing, dialogic manner. This is most clearly seen in the perceived threat of minority languages to majority languages - 
as if, somewhat implausibly, their greater recognition will somehow fatally undermine the dominant state language. The US English movement is the baldest/crudest example of this, although it is also demonstrably evident in more academic analyses, as has been discussed above.

Dismantling the identity-instrumental opposition between minority and majority languages, however, immediately brings into question the idea of incommensurate linguistic identities on which it is based. In other words, the distinctions often made by MLR opponents with respect to majority and minority languages are themselves predicated on a singular, exclusive and oppositional notion of linguistic identity - people must have one linguistic identity or the other, they cannot have both.

In contrast, MLR actually provides for a far more pluralistic, open-ended interpretation of language and identity - that is, the opportunity or potential for holding multiple, complementary cultural and linguistic identities at both individual and collective levels. On this view, maintaining one's minority ethnically affiliated language - or a dominant language, for that matter - avoids 'freezing' the development of particular languages in the roles they have historically occupied, or perhaps still currently occupy. ${ }^{12}$ Equally importantly, it questions and discards the requirement of a singular and / or replacement approach to the issue of other linguistic identities. Linguistic identities - and social and cultural identities more broadly - need not be constructed as irredeemably oppositional. Narrower identities do not necessarily need to be traded in for broader ones. One can clearly remain, for example, both Spanish speaking and American, Catalan speaking and Spanish, or Welsh speaking and British. The same process applies to national and international language identities, where these differ. To insist otherwise, as many critics of MLR do, betrays, ironically, both a reductionist and an essentialist approach to language and identity. In other words, a key challenge for MLR critics is to start applying the constructivist critique that they regularly employ against MLR far more closely and critically to their own analyses. In so doing, the question they have to address, and have yet to answer adequately, is: 'what exactly is wrong with linguistic complementarity as an LPP goal'?

The problems of reductionism and essentialism are also clearly evident in the position that MLR critics adopt on the issue of bilingual and / or mother-tongue education (see May, 2003 for an extended discussion). What is constructed here is a bipolar approach to language education, in line with the previous idea of incommensurable linguistic identities. Either learn the dominant language through submersion in that language or choose to exit from this opportunity via bilingual education. As was seen in the discussion of mobility, these arguments were clearly articulated by the political theorists Pogge (2003) and Laitin and Reich (2003). Laitin and Reich observed, for example, that the consequence of 'forcing' bilingual education on children would be the curtailing of 'their opportunities to learn the language of some broader societal culture'. And Pogge concluded that a public education in English, as opposed to a bilingual approach, is unquestionably in the 'best interests of the child' in relation both to developing 'fluency in English' and in 'enabling all students to participate fully in US society'. Barry (2000) has argued much the same position, following earlier commentators such as Schlesinger (1992) and Hughes (1993).

The problem with these arguments is that the educational and linguistic 
premises upon which they are based are nonsense. For a start, they reveal a deeply uncritical and highly normative view of English monolingualism, and a related and deeply flawed understanding of bilingualism and bilingual education. In the process, what is conveniently overlooked is that educational and linguistic research over the last 40 years has demonstrated unequivocally that bilingualism is a cognitive advantage rather than a deficit ${ }^{13}$ and that being educated in one's first-language provides the most effective means of subsequently transferring those first language skills to a second language. Conversely, being submerged too early in a second language, such as the English-submersion educational approaches advocated for Spanish speakers in the US, has been found to be the least effective educational approach for achieving first-to-second language transfer (see Baker, 2001; Corson, 1998; Cummins, 1996, 1999). ${ }^{14}$ When this is recognised and acknowledged, a central premise of MLR critics - that individual mobility for minority-language speakers is most effectively achieved via the dominant language, or at least only in the dominant language - is fatally undermined.

Finally, let me return again to the question of consistency. There are not many critics of MLR arguing that 'elite' bilingualism - say, learning English and French - is injurious to one's involvement in and grasp of 'broader societal culture'. Quite the reverse in fact, as was seen, for example, from Barry's comments above. So, why should it be different for any other language? Why should bilingualism be good for the rich but not for the poor (Cummins, 2001)? What should be separated out here, then, are the educational and linguistic factors in learning other languages (including learning in other languages) and the broader social and political issues concerning the perceived status of the particular languages involved. In so doing, it is possible to begin to deconstruct and critique the rhetorical move often employed by MLR critics in this instance; that is, to attempt to discredit the educational and linguistic merits of bilingual education on the basis of the political challenge it presents for a monolingual conception of the nation-state (see May, 2001).

\section{Conclusion}

To conclude, I want to suggest that, despite the considerable criticisms levelled against them, minority-language rights are still worth pursuing. Certainly, as I have tried to show here, there is no reason why MLR cannot develop a position that effectively acknowledges and addresses the concerns raised by its many opponents. That said, the real challenge for MLR is the same as it has always been: to influence, and if possible change, the wider social, cultural and political processes that have seen the construction of and distinction between so-called minority and majority languages in the first place.

The implications of this challenge for language planning and policy (LPP) are significant. The MLR challenge requires LPP to address centrally and critically the wider social and political conditions - and, crucially, their historical antecedents - that have invariably framed and shaped existing language policies which privilege, and normalise, majority languages. As Jan Blommaert argues, an approach to LPP that fails to do so takes no account of human agency, political intervention, power and authority in the formation of particular (national) 
language ideologies. Nor, by definition, is it able to identify the establishment and maintenance of majority languages as a specific ' form of practice, historically contingent and socially embedded' (Blommaert, 1999: 7). And yet, as MLR advocates quite clearly highlight, it is exactly these contingent, socially embedded, and often highly unequal practices, that have so disadvantaged minority languages, and their speakers, in the first place.

These MLR arguments also resonate closely with important related research on the ideological influences of language policy (Blommaert, 1999; May, 2001; Ricento, 2000; Schiffman, 1996; Schmid, 2001; Woolard, 1998). As a result of this combination of research influences, recent LPP scholarship (see e.g. Baldauf \& Kaplan, 2003; Maurais \& Morris, 2003; May, 2005; Tollefson, 2001) is increasingly addressing the overtly political and ideological aspects of language policy and planning, along with its often deleterious consequences for minority-language speakers. Whether this nascent academic direction for LPP is sustained and, more importantly perhaps, whether the long-standing pejorative position (and positioning) of minority-language speakers will improve, remains to be seen.

In short, instantiating MLR within particular language-policy contexts clearly remains a formidable task - and it must be acknowledged that it may indeed be an impossible one. After all, the social and political forces arraigned against minority languages, and in favour of the ongoing processes of linguistic 'modernisation', remain both firmly in place and considerable. But if one can hold onto the fact that the MLR movement has so usefully highlighted - that processes of linguistic change are often, if not always, the result of wider social and political processes - then this provides a useful basis from which to mount an effective political challenge on behalf of minority languages. From this, one can also question and critique the apparently ineluctable link between majority languages, mobility and 'progress', and in turn look to ways in which minority languages may be reconstituted not simply as 'carriers' of identity but also as instrumentally useful. ${ }^{15}$

If MLR can accomplish this, there just might be a chance, however slim, of changing the current parlous circumstances of at least some minority languages, along with those of their speakers, for the better. For all the complexities and difficulties attendant upon such a task, this still seems a goal worth fighting for.

\section{Correspondence}

Any correspondence should be directed to Professor Stephen May, School of Education, University of Waikato, Private Bag 3105, Hamilton, New Zealand (s.may@waikato.ac.nz).

\section{Notes}

1. In what follows, I employ the usual distinction between so-called 'minority' and 'majority' languages in MLR literature; a distinction that is based not on numerical size, but on clearly observable differences among language varieties in relation to power, status and entitlement. That said, such a distinction needs to be treated with some caution since the dichotomy inevitably understates the complex situatedness of particular language varieties with respect to power relations (Coulmas, 1998; Pennycook, 1998).

2. I have responded at length elsewhere to other perceived criticisms of MLR, particularly 
those to do with their supposed threat to political stability (see May, 2000a, 2001, 2003).

3. For examples of this position within sociolinguistics, see Bentahila and Davies 1993; Brutt-Griffler, 2002; Coulmas, 1992; Edwards, 1984; Ladefoged, 1992. For examples within social and political theory, see Barry, 2000; Laitin and Reich, 2003; Pogge, 2003; Schlesinger, 1992. It should be noted, however, that even among these examples there are considerable differences of degree and intensity in the criticism of MLR.

4. Such views are also echoed in the developing world and are well represented by Kay's (1993) arguments on the 'new African'. Kay's case study of Zambia demonstrates how the country is currently divided into 72 ethnic and seven regional languages but is united by one official language, English. From this, Kay argues for the displacement of African languages in favour of international languages such as English. African languages, with their reduced communicative power and symbolic purchase, reflect for Kay the old order while the likes of English now represent the best means of escaping both poverty and the strictures of ethnic identity in Africa. Consequently, language loss is seen as a necessary, perhaps inevitable aspect of modernisation and development, even if, in the process, it risks the 'destruction' of cultures (see also Eastman, 1991; Mazrui, 1975).

5. A comparable 'primordial' account in the sociology of nationalism can be found in the 'linguistic nationalism' of the 18th-century 'German Romantics', Herder and Humboldt and Fichte, who argued that culture, and particularly language, were central to the essence or character (Volksgeist) of the nation. In this perspective, language came to be constructed as the most important distinguishing characteristic of nationhood - indeed, its very soul. The interrelationship between language and the soul or spirit of the nation is most clearly stated by von Humboldt: '[the nation's] language is its spirit and its spirit is its language' (see Cowan, 1963: 277). Or, as he observes elsewhere: 'From every language we can infer backwards to the national character' (Humboldt, 1988: 154). Put another way, the continuing existence of a nation was inconceivable without its own language. Without a language, Herder argued, a Volk is an absurdity (Unding), a contradiction in terms (see Barnard, 1965: 57). As with the sociology of ethnicity, these arguments for linguistic nationalism have long since been dismissed as both essentialist and determinist, and rightly so.

6. Underpinning the precept of 'stable diglossia' was the highly problematic concept of linguistic complementarity. Linguistic complementarity, as understood by early language planners, implied at least some degree of mutuality and reciprocity, along with a certain demarcation and boundedness between the majority and minority languages involved. Situations of so-called stable diglossia, however, are precisely not complementary in these respects. Rather, the normative ascendancy of national languages - and by extension, international languages such as English - specifically militates against the ongoing use, and even existence, of minority languages. As Dua observes of the influence of English in India, for example, 'the complementarity of English with indigenous languages tends to go up in favour of English partly because it is dynamic and cumulative in nature and scope, partly because it is sustained by socio-economic and market forces and partly because the educational system reproduces and legitimatises the relations of power and knowledge implicated with English' (Dua, 1994: 132).

7. The term 'linguistic genocide' is often viewed as highly problematic by critics of minority language rights - as too emotive and conspiratorial. Skutnabb-Kangas argues, in response, that terms such as 'language death' and 'language loss', which many of these sceptics prefer, have significant problems of their own - not least the notable absence of agency or responsibility. Language 'loss' or 'death' does not just happen, nor is it natural and / or inevitable. Rather, it is always socially, culturally and politically situated within a wider nexus of (often highly unequal) power relations between, and within, language groups.

8. Language loss is not only, perhaps not even primarily, a linguistic issue - it has much more to do with power, prejudice, (unequal) competition and, in many cases, overt 
discrimination and subordination. As Noam Chomsky asserts: 'Questions of language are basically questions of power' (Chomsky, 1979: 191). Thus, it should come as no surprise that the vast majority of today's threatened languages are spoken by socially and politically marginalised and / or subordinated groups. These groups have been variously estimated at between 5000 and 8000 (Stavenhagen, 1992) and include within them the 250-300 million members of the world's indigenous peoples (Davis, 1999; Tully, 1995), perhaps the most marginalised of all people groups. As Crawford (1994) notes, language death seldom occurs in communities of wealth and privilege, but rather to the dispossessed and disempowered. Moreover, linguistic dislocation for a particular community of speakers seldom, if ever, occurs in isolation from sociocultural and socioeconomic dislocation as well (Fishman, 1995).

9. For a critique of the 'self-interested elite' position with respect to social movements generally, see Brubaker 1998: 289-92.

10. In Garcia v. Spun Steak (1993), Spanish-speaking workers lodged a claim of language discrimination, under the 14th Amendment, on the grounds that their employer prohibited them from speaking privately in Spanish to each other while at work. This claim was eventually unsuccessful because the court declined to examine the principal point raised by the Spanish-speaking workers: that is, if some employees have the privilege of conversing with others privately at work in their primary language, they should not be denied the same privilege (de Varennes, 1996a).

11. The examples where this has occurred as the result of a minority-language policy remain extremely rare. The post-Soviet language policies of Latvia and Estonia, however, may be said to fall into this category. This is because the significant majority Russian-speaking population in these areas have been denied citizenship rights since independence unless they can demonstrate a conversational ability in Latvian or Estonian (see de Varennes, 1996a).

12. For example, Welsh was historically regarded as the language of 'the chapel' - indeed, this is primarily what kept the language alive over time - but this is diminishing rapidly now, as a result of the church's own diminishing influence in Wales. Likewise, while Welsh was excluded for over four centuries as a language of the state and government, it is clearly in the process now of being reinstantiated in the public domain, as my earlier discussion makes clear (see also May, 2000b, 2001: Ch. 7).

13. There are now close to 150 major research studies, carried out since the early 1960 s, which consistently report significant advantages for bilingual students on a range of metalinguistic and cognitive tasks. As a result, it is now widely recognised that bilinguals mature earlier than monolinguals in acquiring skills for linguistic abstraction, are superior to monolinguals on divergent thinking tasks and in their analytical orientation to language, and demonstrate greater social sensitivity than monolinguals in situations requiring verbal communication (see Baker, 2001, Corson, 1998; Cummins, 1996, 2001; Romaine, 1995).

14. This is in direct contradiction to Pogge's assertion at one point, for example, that 'children's important long-term interest in being fully literate in English is best served by early immersion [in English]' (Pogge, 2003: 119).

15. Establishing this increased instrumentality for minority languages does not necessarily require their full reintegration into the public domain, as in the case of Wales (or Catalunya, or Quebec). There is clearly a continuum of use here, depending on the status and reach of particular minority languages, along with the number of speakers. Education is one alternative - or, more accurately, allied - arena where the linguistic instrumentality of minority languages can be re-established (see May, 2001). Many community-based indigenous language education initiatives, for example, often involve small-scale, local community-based initiatives (see May, 1999b; May \& Aikman, 2003; McCarty \& Zepeda, 1995). Even here though, there can be considerable differences of scale and influence, depending on the wider political context. In Aotearoa / New Zealand, Finnmark in Norway, and Nunavut in Canada, for example, there are significant indigenous education initiatives that have been recognised at national or regional level (see May, 2001: Ch. 8). 


\section{References}

Anderson, B. (1991) Imagined Communities: Reflections on the Origin and Spread of Nationalism (rev. edn). London: Verso.

Baker, C. (2001) Foundations of Bilingual Education and Bilingualism (3rd edn). Clevedon: Multilingual Matters.

Baldauf, R. and Kaplan, R. (2003) Who are the actors? The role of (applied) linguists in language policy. In P. Ryan and R. Terborg (eds) Language: Issues of Inequality. Mexico City: CELE/ Autonomous National University of Mexico.

Banton, M. (1980) Ethnic groups and the theory of rational choice. In Sociological Theories: Race and Colonialism (pp. 475-83). Paris: UNESCO.

Banton, M. (1987) Racial Theories. Cambridge: Cambridge University Press.

Barnard, F. (1965) Herder's Social and Political Thought: From Enlightenment to Nationalism. Oxford: Clarendon.

Barry, B. (2000) Culture and Equality: An Egalitarian Critique of Multiculturalism. Cambridge, MA: Harvard University Press.

Barth, F. (1969) Introduction. In Ethnic Groups and Boundaries: The Social Organization of Culture Difference (pp. 9-38). Boston, MA: Little, Brown.

Bentahila, A. and Davies, E. (1993) Language revival: Restoration or transformation? Journal of Multilingual and Multicultural Development 14, 355-74.

Blommaert, J. (1996) Language and nationalism: Comparing Flanders and Tanzania. Nations and Nationalism 2, 235-56.

Blommaert, J. (ed.) (1999) Language Ideological Debates. Berlin: Mouton de Gruyter.

Blommaert, J. (2001) The Asmara Declaration as a sociolinguistic problem: Notes in scholarship and linguistic rights. Journal of Sociolinguistics 5 (1), 131-42.

Bourdieu, P. (1984) Distinction: A Social Critique of the Judgement of Taste. Cambridge, MA: Harvard University Press.

Bourdieu, P. (1990a) In Other Words: Essays Towards a Reflexive Sociology. Cambridge: Polity.

Bourdieu, P. (1990b) The Logic of Practice. Cambridge: Polity.

Bourdieu, P. (1991) Language and Symbolic Power. Cambridge: Polity.

Bourdieu, P. and Passeron, J-C. (1990) Reproduction in Education, Society and Culture (2nd edn). London: Sage.

Bourdieu, P. and Wacquant, L. (1992) An Invitation to Reflexive Sociology. Chicago, IL: Chicago University Press.

Brubaker, R. (1998) Myths and misconceptions in the study of nationalism. In J. Hall (ed.) The State of the Nation: Ernest Gellner and the Theory of Nationalism (pp. 272-306). Cambridge: Cambridge University Press.

Brutt-Griffler, J. (2002) Class, ethnicity and language rights: An analysis of British colonial policy in Lesotho and Sri Lanka and some implications for language policy. Journal of Language, Identity and Education 1 (3), 207-234.

Capotorti, F. (1979) Study on the Rights of Persons Belonging to Ethnic, Religious and Linguistic Minorities. New York: United Nations.

Carens, J. (2000) Culture, Citizenship and Community: A Contextual Exploration of Justice as Evenhandedness. Oxford: Oxford University Press.

Chomsky, N. (1979) Language and Responsibility. London: Harvester.

Corson, D. (1998) Changing Education for Diversity. Buckingham: Open University Press.

Coulmas, F. (1992) Language and Economy. Oxford: Blackwell.

Coulmas, F. (1998) Language rights: Interests of states, language groups and the individual. Language Sciences 20, 63-72.

Cowan, M. (1963) Humanist Without Portfolio: An Anthology of the Writings of Wilhelm von Humboldt. Detroit, MI: Wayne State University Press.

Crawford, J. (ed.) (1992) Language Loyalties: A Source Book on the Official English Controversy. Chicago, IL: University of Chicago Press.

Crawford, J. (1994) Endangered Native American languages: What is to be done and why? Journal of Navajo Education 11 (3), 3-11.

Cummins, J. (1996) Negotiating Identities: Education for Empowerment in a Diverse Society. Toronto: California Association for Bilingual Education. 
Cummins, J. (1999) Alternative paradigms in bilingual education research: Does theory have a place? Educational Researcher 28 (7), 26-32.

Cummins, J. (2001) Language, Power and Pedagogy: Bilingual Children in the Crossfire. Clevedon: Multilingual Matters.

Davis, W. (1999) Vanishing cultures. National Geographic (August), 62-89.

de Varennes, F. (1996a) Language, Minorities and Human Rights. The Hague: Kluwer Law International.

de Varennes, F. (1996b) Minority aspirations and the revival of indigenous peoples. International Review of Education 42, 309-25.

Dicker, S. (2000) Official English and bilingual education: The controversy over language pluralism in US society. In J. Kelly Hall and W. Eggington (eds) The Sociopolitics of English Language Teaching (pp. 45-66). Clevedon: Multilingual Matters.

Di Maggio, P. (1979) Review essay on Pierre Bourdieu. American Journal of Sociology 84, 1460-74.

Dorian, N. (1981) Language Death. Philadelphia, PA: University of Pennsylvania Press.

Dorian, N. (1982) Language loss and maintenance in language contact situations. In R. Lambert and B. Freed (eds) The Loss of Language Skills (pp. 44-59). Rowley, MA: Newbury House.

Dua, H. (1994) Hegemony of English. Mysore: Yashoda.

Eastman, C. (1984) Language, ethnic identity and change. In J. Edwards (ed.) Linguistic Minorities, Policies and Pluralism (pp. 259-76). London: Academic.

Eastman, C. (1991) The political and sociolinguistic status of language planning in Africa. In D. Marshall (ed.) Language Planning: Focusschrift in Honour of Joshua A. Fishman (pp. 131-51). Amsterdam: John Benjamins.

Edwards, J. (1984) Language, diversity and identity. In J. Edwards (ed.) Linguistic Minorities, Policies and Pluralism (pp. 277-310). London: Academic.

Edwards, J. (1985) Language, Society and Identity. Oxford: Basil Blackwell.

Edwards, J. (1994) Multilingualism. London: Routledge.

Edwards, J. (2001) The ecology of language revival. Current Issues in Language Planning 2, 231-41.

Eriksen, T. (1993) Ethnicity and Nationalism: Anthropological Perspectives. London: Pluto.

Fenton, S. (1999) Ethnicity: Racism, Class and Culture. London: Macmillan.

Fishman, J. (1968a) Sociolinguistics and the language problems of the developing countries. In J. Fishman, C. Ferguson and J. Das Gupta (eds) Language Problems of Developing Nations (pp. 3-16). New York: Wiley.

Fishman, J. (1968b) Some contrasts between linguistically homogeneous and linguistic heterogeneous polities. In J. Fishman, C. Ferguson and J. Das Gupta (eds) Language Problems of Developing Nations (pp. 53-68). New York: Wiley.

Fishman, J. (1968c) Language problems and types of political and sociocultural integration: A conceptual postscript. In J. Fishman, C. Ferguson and J. Das Gupta (eds) Language Problems of Developing Nations (pp. 491-8). New York: Wiley.

Fishman, J. (1995) Good conferences in a wicked world: On some worrisome problems in the study of language maintenance and language shift. In W. Fase, K. Jaspaert and S. Kroon (eds) The State of Minority Languages: International Perspectives on Survival and Decline. Lisse, Netherlands: Swets and Zeitlinger.

Fishman, J. (1997) Language and ethnicity: The view from within. In F. Coulmas (ed.) The Handbook of Sociolinguistics (pp. 327-43). London: Blackwell.

Fox, M.J. (1975) Language and Development: A Retrospective Survey of Ford Foundation Language Projects 1952-1974.

Garcia, O. (1995) Spanish language loss as a determinant of income among Latinos in the United States: Implications for language policies in schools. In J. Tollefson (ed.) Power and Inequality in Language Education (pp. 142-60). Cambridge: Cambridge University Press.

Grin, F. (1995) Combining immigrant and autochthonous language rights: A territorial approach to multilingualism. In T. Skutnabb-Kangas and R. Phillipson (eds) Linguistic Human Rights: Overcoming Linguistic Discrimination (pp. 31-48). Berlin: Mouton de Gruyter. 
Harker, R. (1984). On reproduction, habitus and education. British Journal of Sociology of Education 5, 117-27.

Harker, R. (1990) Bourdieu: Education and reproduction. In R. Harker, C. Mahar and C. Wilkes (eds) An Introduction to the Work of Pierre Bourdieu: The Practice of Theory (pp. 86-108). London: Macmillan.

Harker, R. and May, S. (1993) Code and habitus: Comparing the accounts of Bernstein and Bourdieu. British Journal of Sociology of Education 14, 169-78.

Harmon, D. (1995) The status of the world's languages as reported in the Ethnologue. Southwest Journal of Linguistics 14, 1-28.

Hechter, M. (1986) Rational choice theory and the study of race and ethnic relations. In J. Rex and D. Mason (eds) Theories of Race and Race Relations (pp. 264-79). Cambridge: Cambridge University Press.

Hechter, M. (1987) Principles of Group Solidarity. Berkeley, CA: University of California Press.

Heller, M. (1987) The role of language in the formation of ethnic identity. In J. Phinney and M. Rotheram (eds) Children's Ethnic Socialisation: Pluralism and development (pp. 180-200). Newbury Park, CA: Sage.

Heller, M. (1999) Linguistic Minorities and Modernity: A Sociolinguistic Ethnography. London: Longman.

Henrard, K. (2000) Devising an Adequate System of Minority Protection. The Hague: Kluwer Law.

Hughes, R. (1993) Culture of Complaint: The Fraying of America. New York: Oxford University Press.

Humboldt, W. von (1988) On Language: The Diversity of Human Language Structure and its Influence on the Mental Development of Mankind (trans. P. Heath) (1st edn 1836). Cambridge: Cambridge University Press.

Jenkins, R. (1997) Rethinking Ethnicity: Arguments and Explorations. London: Sage.

Kaplan, R. and Baldauf, R. (1999) Language Planning in Malawi, Mozambique and the Philippines. Clevedon: Multilingual Matters.

Kay, G. (1993) Ethnicity, the cosmos and economic development, with special reference to Central Africa. Mimeo.

Khleif, B. (1979) Insiders, outsiders and renegades: Towards a classification of ethnolinguistic labels. In H. Giles and B. Saint-Jacques (eds) Language and Ethnic Relations (pp. 159-72). Oxford: Pergamon.

Kloss, H. (1968) Notes concerning a language-nation typology. In J. Fishman, C. Ferguson and J. Das Gupta (eds) Language Problems of Developing Nations (pp. 69-85). New York: Wiley.

Kontra, M., Skutnabb-Kangas, T., Phillipson, R. and Várady, T. (eds) (1999) Language: A Right and a Resource. Approaches to Linguistic Human Rights. Budapest: Central European University Press.

Kymlicka, W. (1995) Multicultural Citizenship: A Liberal Theory of Minority Rights. Oxford: Clarendon Press.

Ladefoged, P. (1992) Another view of endangered languages. Language 68, 809-11.

Laitin, D. and Reich, R. (2003) A liberal democratic approach to language justice. In W. Kymlicka and A. Patten (eds) Language Rights and Political Theory (pp. 80-104). Oxford: Oxford University Press.

Lukes, S. (1996) Humiliation and the politics of identity. Social Research 64, 36-51.

Macedo, D. (1994) Literacies of Power: What Americans Are Not Allowed to Know. Boulder, CO: Westview.

Maffi, L. (ed.) (2000). Language, Knowledge and the Environment: The Interdependence of Biological and Cultural Diversity. Washington, DC: Smithsonian Institution.

Maffi, L. (2001) On Biocultural Diversity: Linking Language, Knowledge, and the Environment. Washington, DC: Smithsonian Institution.

Maurais, J. and Morris, M. (2003) Languages in a Globalising World. Cambridge: Cambridge University Press.

May, S. (1999a) Critical multiculturalism and cultural difference: Avoiding essentialism. 
In S. May (ed.) Critical Multiculturalism: Rethinking Multicultural and Antiracist Education (pp. 11-41). London/ New York: Routledge Falmer.

May, S. (ed.) (1999b) Indigenous Community-based Education. Clevedon: Multilingual Matters.

May, S. (2000a) Uncommon languages: The challenges and possibilities of minority language rights. Journal of Multilingual and Multicultural Development 21 (5), 366-85.

May, S. (2000b) Accommodating and resisting minority language policy: The case of Wales. International Journal of Bilingual Education and Bilingualism 3 (2), 101-28.

May, S. (2001) Language and Minority Rights: Ethnicity, Nationalism and the Politics of Language. London: Longman.

May, S. (2002) Developing greater ethnolinguistic democracy in Europe: Minority language policies, nation-states, and the question of tolerability. Sociolinguistica 16, $1-13$.

May, S. (2003) Misconceiving minority language rights: Implications for liberal political theory. In W. Kymlicka and A. Patten (eds) Language Rights and Political Theory (pp. 123-52). Oxford: Oxford University Press.

May, S. (2005) Language policy and minority language rights. In. E. Hinkel (ed.) Handbook of Research in Second Language Teaching and Learning. Mahwah, NJ: Lawrence Erlbaum.

May, S. and Aikman, S. (2003) Indigenous education: New possibilities, ongoing restraints. Comparative Education 39 (special issue), 2.

Mazrui, A. (1975) The Political Sociology of the English Language: An African Perspective. The Hague: Mouton.

McCarty, T. and Zepeda, O. (eds) (1995) Special issue: Indigenous language education and literacy. Bilingual Research Journal 19 (1).

Mühlhäusler, P. (1996) Linguistic Ecology: Language Change and Linguistic Imperialism in the Pacific Region. London: Routledge.

Mühlhäusler, P. (2000) Language planning and language ecology. Current Issues in Language Planning 1 (3), 306-67.

Nagel, J. (1994) Constructing ethnicity: Creating and recreating ethnic identity and culture. Social Problems 41, 152-76.

Nettle, D. and Romaine, S. (2000) Vanishing Voices: The Extinction of the World's Languages. Oxford: Oxford University Press.

Norton, B. (2000) Identity and Language Learning: Gender, Ethnicity and Educational Change. London: Longman.

Pennycook, A. (1998) The right to language: Towards a situated ethics of language possibilities. Language Sciences 20, 73-87.

Pennycook, A. (2001) Critical Applied Linguistics. Mahwah, NJ: Lawrence Erlbaum.

Phillipson, R. (2003) English-Only Europe/Challenging Language Policy. London: Routledge.

Pinker, S. (1995) The Language Instinct. London: Penguin.

Pogge, T. (2003) Accommodation rights for Hispanics in the US. In W. Kymlicka and A. Patten (eds) Language Rights and Political Theory (pp. 105-22). Oxford: Oxford University Press.

Renan, E. (1990) (first published 1882) What is a nation? In H. Bhabha (ed.) Nation and Narration (pp. 8-22). London: Routledge.

Ricento, T. (2000) Historical and theoretical perspectives in language policy and planning. In T. Ricento (ed.) Ideology, Politics and Language Policies: Focus on English (pp. 9-24). Amsterdam: John Benjamins.

Romaine, S. (1995) Bilingualism (2nd edn). Oxford: Blackwell.

Rubin, J. and Jernudd, B. (eds) (1971) Can Language be Planned? Sociolinguistic Theory and Practice for Developing Nations. Hawaii: University of Hawaii Press.

San Miguel, G. and Valencia, R. (1998) From the Treaty of Guadalupe Hidalgo to Hopwood: The educational plight and struggle of Mexican Americans in the Southwest. Harvard Educational Review 68, 353-412.

Schiffman, H. (1996) Linguistic Culture and Language Policy. London: Routledge.

Schlesinger, A. (1992) The Disuniting of America: Reflections on a Multicultural Society. New York: Norton. 
Schmid, C. (2001) The Politics of Language: Conflict, Identity, and Cultural Pluralism in a Comparative Perspective. Oxford: Oxford University Press.

Secada, W. and Lightfoot, T. (1993) Symbols and the political context of bilingual education in the United States. In M. Arias and U. Casanova (eds) Bilingual Education: Politics, Practice, and Research (pp. 36-64). Chicago, IL: National Society for the Study of Education/University of Chicago Press.

Skutnabb-Kangas, T. (1998) Human rights and language wrongs - a future for diversity? Language Sciences 20, 5-27.

Skutnabb-Kangas, T. (2000) Linguistic Genocide in Education - or Worldwide Diversity and Human Rights? Mahwah, NJ: Lawrence Erlbaum.

Skutnabb-Kangas, T. (2002) Marvellous human rights rhetoric and grim realities: Language rights in education. Journal of Language, Identity and Education 1 (3), 179-206.

Skutnabb-Kangas, T. and Phillipson, R. (1995) Linguistic human rights, past and present. In T. Skutnabb-Kangas and R. Phillipson (eds) Linguistic Human Rights: Overcoming Linguistic Discrimination (pp. 71-110). Berlin: Mouton de Gruyter.

Stavenhagen, R. (1992) Universal human rights and the cultures of indigenous peoples and other ethnic groups: The critical frontier of the 1990s. In A. Eide and B. Hagtvet (eds) Human Rights in Perspective (pp. 135-51). Oxford: Blackwell.

Tabouret-Keller, A. (1997) Language and identity. In F. Coulmas (ed.) The Handbook of Sociolinguistics (pp. 315-26). Oxford: Blackwell.

Thornberry, P. (1991a) International Law and the Rights of Minorities. Oxford: Clarendon.

Thornberry, P. (1991b) Minorities and Human Rights Law. London: Minority Rights Group.

Tollefson, J. (2001) Language policy/planning and disadvantages. In R. Kaplan (ed.) Oxford Handbook of Applied Linguistics (pp. 415-23). Oxford: Oxford University Press.

Toynbee, A. (1953) A Study of History (Vols. VII-IX). London: Oxford University Press.

Tully, J. (1995) Strange Multiplicity: Constitutionalism in an Age of Diversity. Cambridge: Cambridge University Press.

Weinstein, B. (1983) The Civic Tongue: Political Consequences of Language Choices. New York: Longman.

Weinstein, B. (1990) Language Policy and Political Development. Norwood, NJ: Ablex.

Welsh Language Board (1995) Draft Guidelines as to the Form and Content of Schemes. Cardiff: Welsh Language Board.

Werbner, P. (1997). Essentialising essentialism, essentialising silence: Ambivalence and multiplicity in the constructions of racism and ethnicity. In P. Werbner and T. Modood (eds) Debating Cultural Hybridity: Multicultural Identities and the Politics of Antiracism (pp. 226-54). London: Zed.

Woolard, K. (1998) Introduction: Language ideology as a field of inquiry. In B. Schieffelin, K. Woolard and P. Kroskrity (eds) Language Ideologies: Practice and Theory (pp. 3-47). New York: Oxford University Press.

\section{The Author}

Stephen May is Foundation Professor and Chair of Language and Literacy Education in the School of Education and Research Professor in the Wilf Malcolm Institute of Educational Research, University of Waikato, Hamilton, New Zealand. He has written widely on language and education, with a particular focus on addressing and accommodating cultural and linguistic diversity. Areas of particular interest and expertise include: language rights, bilingualism and bilingual education, indigenous education, and multicultural education. Additional research interests are in the wider politics of multiculturalism, ethnicity and nationalism, social theory (particularly the work of Bourdieu), sociolinguistics and language policy, school language policies, and critical and qualitative research methods. 